\title{
MANAJEMEN PESERTA DIDIK RAUDLATUL ATHFAL (RA)
}

\author{
Oleh: Fu'ad Arif Noor
}

Dosen STPI Bina Insan Mulia Yogyakarta

\begin{abstract}
This research is to know the concept of learners Raudlatul Athfal in the acceptance and learning as well as management of learners Raudlatul Athfal that presence is needed at the unit level educational institutions of $R A$. Learners are the subject and object in the process of transforming knowledge and skills as the main foundation for the initial and early childhood. Management learners are aimed at regulating how the various activities that lead to growth and development potential learners Raudlatul Athfal the age of 4 (four) to 6 (six) this year so that learning activities bias smooth, orderly and organized in order to reach the goal of effective learning and efficiently. Management of learners is defined as a business arrangement to learners from such learners attend school until they graduate. So the management of learner or pupil personnel administration as a service that is focused on the regulation, supervision and services students in the classroom and outside the classroom such as: introduction, registration, individualized services such as the overall development of abilities, interests, needs to he done in school. The level of achievement of development of learners $R A$ include religious values and morals, Physical gross and fine motor, health and safety behavior, cognitive consisting of learning and problem solving, as well as logical and symbolic thinking. For languages include understanding the language, expressing the language, and literacy. Furthermore, the social sphere include the child's emotional self-awareness, a sense of responsibility to oneself and others, as well as prosocial behavior. While the scope of the latest developments include the art of covering children are able to enjoy a variety of strains of the song or sound and interested in art activities.
\end{abstract}

Keywords: Management, Students, Raudlatul Athfal, RA. 
Fu'ad Arif Noor : Manajemen Peserta Didik Raudlatul Athfal (RA)

\begin{abstract}
Abstrak
Penelitian ini adalah untuk mengetahui konsep peserta didik Raudlatul Athfal dalam penerimaan dan belajar serta pengelolaan peserta didik Raudlatul Athfal bahwa kehadiran dibutuhkan di lembaga pendidikan tingkat satuan RA. Peserta didik adalah subjek dan objek dalam proses transformasi pengetahuan dan keterampilan sebagai dasar utama untuk masa awal dan dini. Peserta didik manajemen ditujukan untuk mengatur bagaimana berbagai kegiatan yang mengarah pada peserta didik potensi pertumbuhan dan perkembangan Raudlatul Athfal usia 4 (empat) sampai 6 (enam) tahun ini sehingga kegiatan belajar prategangan halus, tertib dan teratur untuk mencapai tujuan pembelajaran yang efektif dan efisien. Manajemen peserta didik didefinisikan sebagai pengaturan bisnis untuk pelajar dari peserta didik tersebut masuk sekolah sampai mereka lulus. Jadi pengelolaan administrasi peserta didik atau murid personel sebagai layanan yang difokuskan pada regulasi, pengawasan dan layanan siswa di kelas dan di luar kelas seperti: pengenalan, pendaftaran, layanan individual seperti pengembangan keseluruhan kemampuan, minat, kebutuhan untuk dilakukannya di sekolah. Tingkat pencapaian perkembangan peserta didik RA meliputi nilai-nilai agama dan moral, kotor fisik dan motorik halus, kesehatan dan perilaku keselamatan, kognitif terdiri dari belajar dan pemecahan masalah, serta berpikir logis dan simbolis. Untuk bahasa termasuk memahami bahasa, mengungkapkan bahasa, dan keaksaraan. Selain itu, lingkungan sosial termasuk emosional kesadaran diri anak, rasa tanggung jawab untuk diri sendiri dan orang lain, serta perilaku prososial. Sedangkan ruang lingkup perkembangan terbaru termasuk seni meliputi anak-anak dapat menikmati berbagai alunan lagu atau suara dan tertarik pada kegiatan seni.
\end{abstract}

Kata kunci: Manajemen, Mahasiswa, Raudlatul Athfal, RA.

\title{
A. Pendahuluan
}

Sejak adanya gagasan untuk melakukan pengalihan, pelestarian dan pengembangan kebudayaan melalui pendidikan, maka sejak itu manusia menghendaki kemajuan dalam kehidupannya. Oleh karena itu pendidikan di dalam masyarakat 
senantiasa menjadi perhatian utama dalam rangka memajukan kehidupan generasi selanjutnya yang sejalan dengan tuntunan, perkembangan dan kemajuan masyarakat dari zaman ke zaman.

Manusia adalah subyek dan objek pendidikan, manusia dewasa yang berkebudayaan adalah subyek pendidikan dalam arti yang bertanggung jawab menyelenggarakan pendidikan. Mereka berkewajiban secara moral atas perkembangan pribadi anak-anak mereka, generasi penerus mereka. Manusia dewasa yang berkebudayaan terutama yang berpotensi keguruan (pendidikan) bertanggung jawab formal untuk melaksanakan misi pendidikan sesuai dengan tujuan dan nilai-nilai yang dikehendaki oleh masyarakat bangsa itu. 99

Para praktisi pendidikan mensepakati bahwa pendidikan bisa berjalan karena dibangun oleh beberapa komponen dasar, seperti guru, murid, kurikulum, bangunan, fisik, media pembelajaran dan sebagainya. Namun dari kesemuanya yang dianggap mendasar adalah faktor kompunen manusia yang terlibat dalam pelaksanaan pendidikan merupakan faktor yang paling menentukan. ${ }^{100}$

Unsur kedua yang memegang peranan penting dalam pendidikan adalah peserta didik atau murid. Murid adalah manusia yang akan dibentuk oleh dunia pendidikan. Ia adalah objek sekaligus subjek, yang tanpa keberadaannnya proses pendidikan mustahil berjalan. Dalam belajar mengajar, guru dan murid memegang peranan penting. Murid atau peserta didik adalah pribadi yang unik yang mempunyai potensi dan mengalami

99 Sitti Nadirah, Anak Didik Perspektif Nativisme, Empirisme, dan Konvergensi, (Palu : Lentera Pendidikan, Vol. 16 No. 2 Desember 2013), hal. 188

100 Abdul Munir, Seni Mengelola Lembaga Pendidikan Islam, (Ciputat: Arta Karya Indonesia, 2010), hal. 6. 
proses berkembang. Dalam proses berkembang itu anak atau murid membutuhkan bantuan yang sifat dan coraknya tidak ditentukan oleh guru tetapi oleh anak itu sendiri, dalam suatu kehidupan bersama dengan individu-individu yang lain. 101

Murid merupakan potensi kelas yang harus dimanfaatkan guru dalam mewujudkan proses belajar mengajar yang efektif. Murid adalah anak-anak yang sedang tumbuh dan berkembang, baik secara fisik maupun psikologis dalam rangka mencapai tujuan pendidikannya melalui lembaga pendidikan formal, khususnya berupa sekolah. Murid sebagai unsur kelas memiliki perasaan kebersamaan yang sangat penting artinya bagi terciptanya situasi kelas yang dinamis. Setiap murid harus memiliki perasaan diterima (membership) terhadap kelasnya agar mampu ikut serta dalam kegiatan kelas. Perasaan diterima itu akan menentukan sikap bertanggung jawab terhadap kelas yang secara langsung berpengaruh pada pertumbuhan dan perkembangaanya masing-masing. ${ }^{102}$

Peserta didik, menurut ketentuan umum Undang-undang RI tentang Sistem Pendidikan Nasional adalah anggota masyarakat yang berusaha mengembangkan potensi dirinya melalui proses pembelajaran yang tersedia pada jalur, jenjang, dan jenis pendidikan tertentu. Pada perguruan tinggi, menurut ketentuan Peraturan Pemerintah RI Nomor 30 Tahun 1990 disebut mahasiswa. Sedangkan pendidikan dasar dan menengah, menurut ketentuan Pasal 1 Peraturan Pemerintah RI Nomor 28 dan Nomor 29 Tahun 1990, disebut dengan siswa. Sementara

101 Zakiah Daradjat, Metodik Khusus Pengajaran Agama Islam, (Jakarta: Bumi Aksara, 2001), hal. 268.

102 Hadari Nawawi, Organisasi Sekolah dan Pengelolaan Kelas Sebagai Lembaga Pendidikan. (Jakarta: Gunung Agung, 1985), hal. 127-128. 
Pada Taman kanak-kanak, menurut ketentuan Pasal 1 Peraturan Pemerintah RI Nomor 27 Tahun 1990, disebut dengan anak didik. Namun penulis menggunakan istilah yang ada pada Undangundang RI tersebut menggunakan istilah peserta didik.

Peserta didik ini juga mempunyai sebutan-sebutan lain seperti murid, subjek didik, anak didik, pembelajar, siswa, mahasiswa, taruna, warga belajar, pelajar, santri dan sebagainya. ${ }^{103}$ Oleh itu sebutan-sebutan yang berbeda mempunyai maksud yang sama, peserta didik adalah mereka yang sedang mengikuti program pendidikan pada suatu sekolah atau pada jenjang pendidikan tertentu,104 yang selalu ingin mengembangkan potensi dirinya baik pada aspek akademik maupun non akademik melalui proses pembelajaran yang diselenggarakan.

Sementara itu Pendidikan anak usia dini (PAUD) dalam Undang-undang RI No. 20 tahun 2003, pasal 1 ayat 14, Pendidikan anak usia dini adalah suatu upaya pembinaan yang ditujukan kepada anak sejak lahir sampai dengan usia enam tahun yang dilakukan melalui pemberian rangsangan pendidikan untuk membantu pertumbuhan dan perkembangan jasmani dan rohani agar anak memiliki kesiapan dalam memasuki pendidikan lebih lanjut,105 yang diselenggarakan pada jalur formal, nonformal, dan informal. (dijelaskan rinci pada pasal 28 ayat 1-6). Pada pasal 28 ayat 3, bahwa Pendidikan anak usia dini pada jalur

$103 \quad$ http://id.wikipedia.org/wiki/Peserta\%20didik?oldid=8321667 diakses pada 14 Agustus 2015.

104 Ali Imron, Manajemen Peserta Didik Berbasis Sekolah, (Jakarta : Bumi Aksara, 2012), hal. 6.

105 Undang-undang Republik Indonesia No. 20 tahun 2003 tentang Sistem Pendidikan Nasional (Sisdiknas), hlm. 2. 
formal berbentuk Taman Kanak-kanak (TK), Raudlatul Athfal (RA), atau bentuk lain yang sederajat. 106

Satuan pendidikan penyelenggara terdiri dari : Sekolah Dasar Kelas Awal (kelas 1,2,3), Taman Kanak-kanak (TK), Raudatul Athfal (RA), Bustanul Athfal (BA), Kelompok Bermain (KB), Taman Penitipan Anak (TPA), Satuan PAUD Sejenis (SPS), Bina Keluarga Balita, Pos Pelayanan Terpadu (Posyandu), Keluarga, dan Lingkungan. ${ }^{107}$

Peraturan Pemerintah RI. No. 27/1990, tentang : Pendidikan Pra sekolah, Bab I pasal 1 ayat 2, TK adalah salah satu bentuk pendidikan prasekolah yang menyediakan program pendidikan dini bagi anak usia 4 tahun sampai memasuki pendidikan dasar. Keputusan Menteri Pendidikan dan Kebudayaan RI. No. 0486/U/1992, tentang: TK, Bab I pasal 2 ayat 1, bahwa pendidikan TK merupakan wadah untuk membantu pertumbuhan dan perkembangan jasmani dan rohani anak didik sesuai dengan sifat-sifat alami anak. Tindaklanjut dalam Bab II pasal 4, bahwa anak didik di TK adalah anak usia 4 - 6 tahun. Keputusan Menteri Pendidikan dan Kebudayaan RI No. 0125/U/1994, Tentang : Program kegiatan Belajar TK.

Raudlatul Athfal (disingkat RA) adalah salah satu bentuk satuan pendidikan anak pra sekolah pada jalur pendidikan formal yang menyelenggarakan program pendidikan umum dan pendidikan keagamaan Islam bagi anak berusia 4-6 tahun. ${ }^{108}$ RA merupakan jenjang pendidikan anak usia dini (yakni usia 6 tahun

106 Ibid., hal. 18.

107 Ibid., hal. 9

108 Departemen Agama Republik Indonesia, Pedoman Pelaksanaan Kurikulum Raudlatul Athfal, (Jakarta : Direktorat Jenderal Kelembagaan Agama Islam, 2005), hal. 4. 
atau di bawahnya) dalam bentuk pendidikan formal, di bawah pengelolaan Departemen Agama, RA setara dengan taman kanakkanak (TK), dimana kurikulumnya ditekankan pada pemberian rangsangan pendidikan untuk membantu pertumbuhan dan perkembangan jasmani dan rohani agar anak memiliki kesiapan dalam memasuki pendidikan lebih lanjut. Di Indonesia, menempuh pendidikan TK/RA tidaklah wajib.

Manajemen menurut bahasa berarti pemimpin, direksi, pengurus, yang diambil dari kata kerja manage yang berati mengemudikan, mengurus, dan memerintah. Manajemen merupakan kegiatan yang dilakukan oleh manajer dalam memanage organisasi, lembaga, maupun perusahaan. Untuk merealisasikan semua aspek yang terungkap dalam paparan di atas, ternyata tak lepas dari permasalahan manajemen. Bila mau memahami dan menganalisis beberapa macam aspek yang ada bahwa manajemen adalah untuk mengetahui kemana arah yang akan dituju, kesukaran apa yang harus dihadapai, kekuatan apa yang harus dijalankan dan bagaimana mengemudikan kendaraan dengan membuat penumpang nyaman berada di kendaraan yang dikemudikan, bukan malah sebaliknya.

Ali Imron menyimpulkan bahwa manajemen adalah suatu kegiatan yang dilakukan secara bersama-sama oleh dua orang atau lebih yang didasarkan atas aturan tertentu dalam rangka mencapai suatu tujuan. Dua orang atau lebih yang bekerja sama tersebut, karena adanya aturan-aturan tertentu, ada yang berfungsi sebagai manajer dan ada yang dimanajerinya. Orang yang mengelola pekerjaannya tetapi tidak dengan menggunkan tangannya sendiri melainkan tangan orang lain dinamakan manajer. Sementara itu ada pula orang-orang yang dimanajemeni 
dalam bekerja dengan menggunakan tangannya sendiri. Dalam bekerja tersebut, baik yang menjadi manajernya maupun yang dimanaj, dapat mendayagunakan prasarana dan sarana yang tersedia. 109

Dari latar belakang di atas penulis mencoba memadukan dengan mengkaji dan menganalisa persoalan-persoalan yang terkait, yaitu pertama : perihal tentang konsep peserta didik Raudlatul Athfal, yang terdiri dari pengertian dan pemahaman peserta didik Raudlatul Athfal meliputi : potensi, kemampuan, karakteristik, kebutuhan dan masalah-masalah yang dihadapinya. Kedua mengkaji tentang Manajemen peserta didik Raudlatul Athfal, yang meliputi : Perencanaan, pembinaan, dan evaluasi pembelajaran peserta didik.

\section{B. Pembahasan}

\section{Konsep peserta didik Raudlatul Athfal}

Peserta didik adalah seseorang yang berada dalam keadaan belum mempunyai kematangan dalam mencerna dan menyikapi kehidupan yang ada, hal ini sesuai dengan keberadaan dunia anak yang berada dengan dunia orang dewasa, sehingga pola pemahaman anak dengan orang dewasa akan berbeda satu sama lain.

Peserta didik/anak didik yang dilahirkan sebagai anak sangat membutuhkan pertolongan dari orang dewasa guna membantu perkembangannya ke depan. Sebagaimana Abudin Nata menjelaskan bahwa peserta didik itu seorang yang baru belajar, belum memiliki wawasan dan masih amat tergantung kepada guru, ia masih memerlukan masukan berupa

109 Ali Imron, Op. Cit., hal. 5. 
pengetahuan, ketrampilan, pengalaman dan lain sebagainya, sehingga masih banyak memerlukan bimbingan. Yang dalam terminologinya Abudin Nata juga mengelompokkan dalam dua kategori (al-mudarris dan al-tilmidz). ${ }^{110}$ Keberadaan peserta didik bisa dikatakan sebagai makhluk yang tediri dari aspek jasmani dan rohani yang belum mencapai taraf kematangan, baik fisik, mental, spiritual, intelektual, maupun psikologis.

Peserta didik sebagai salah satu komponen pendidikan dalam hal ini memerlukan perhatian yang sangat serius, terlebih selain sebagai objek juga berkedudukan sebagai subjek dalam pendidikan. Dengan kedudukan yang demikian maka keterlibatan peserta didik menjadi salah satu faktor penting dalam terlaksananya proses pendidikan. Dasar hakiki diperlukannya pendidikan bagi peserta didik adalah karena manusia sebagai makhluk sosial yang dapat dibina dan diarahkan untuk mencapai derajat kesusilaan.111 Sehingga anak didik sebagai makhluk sosial yang masih belum mencapai kematangan dalam bersikap sangat memerlukan yang namanya bantuan, bimbingan, dan arahan dari pendidik. Sebagaimana firman Allah SWT. dalam surat AlBaqarah [2] : 31 .

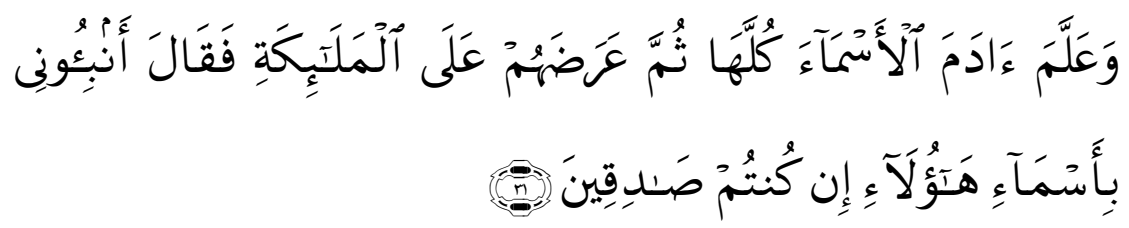

110 Abudin Nata, Perspektif Islam Tentang Pola Hubungan Guru dan Murid, (Jakarta : Raja Grafindo Persada, 2001), hal. 50.

111 Wiji Suwarno , Dasar-dasar Imu Pendidikan, (Yogyakarta : Ar-Ruzz Media, 2006), hal. 36. 
Artinya : "dan Dia mengajarkan kepada Adam Nama-nama (benda-benda) seluruhnya, kemudian mengemukakannya kepada Para Malaikat lalu berfirman: "Sebutkanlah kepada-Ku nama benda-benda itu jika kamu mamang benar orang-orang yang benar!" (Q.S. Al-Baqarah [2] : 31)

Pada ayat tersebut Allah SWT. betindak sebagai yang mengajar (al-mu'allim) dan Nabi Adam As. Berada pada posisi sebagai yang belajar (muta'allim). ${ }^{112}$

Anak didik sebagai peserta didik tidak bisa dipandang pada peran passive yang hanya menerima dan mendengar semua keterangan para pendidik (guru), namun anak didik adalah sosok anak yang mempunyai dunianya sendiri sehingga pemahaman tentang peran passive tidak bisa diberikan kepada peserta didik karena mereka juga akan berperan aktif di dalam dunianya sendiri.

Pendidikan ibarat uang logam, selalu memiliki 2 (dua) sisi. Satu pihak bertugas mengajar, sedangkan pihak lain tugasnya belajar, Satu sisi member, sisi lain menerima. Anak didik merupakan salah satu dari dua sisi tersebut yang memiliki tugas menerima konsep pendidikan agar dalam dirinya terbentuk insan muslim yang tahu akan Tuhan dan agamanya. Demikian pula ia harus memiliki akhlak al-Qur'an, bersikap dan bertindak sesuai dengan kaidah al-Qur'an, berpikir dan berbuat demi kepentingan umat. 113

Pengertian tersebut memberikan arti bahwa peserta didik adalah anak yang belum dewasa, yang dalam artian mencerminkan keinginan untuk tumbuh dan berkembang

112 Ibid., hal. 53.

113 Kamal Muhammad 'Isa, Manajemen Pendidikan Islam, (Jakarta : Bumi Aksara, Cet. II, 2001), hal. 79. 
dari orang lain untuk menjadi dewasa. Anak kandung adalah anak didik keluarga, murid/siswa adalah anak didik di sekolah, anak-anak penduduk adalah anak didik masyarakat di sekitarnya, dan anak umat beragama adalah menjadi anak didik kerohanian agama. Ini semua menandakan bahwa keseluruhan anak tersebut sangat tergantung pada orang dewasa yang harus memahaminya sebagai orang yang sangat membutuhkan bantuan untuk tumbuh dan berkembang sesuai dengan pengertian dan tujuan Raudlatul Athfal.

Jadi peserta didik Raudlatul Athfal adalah anak didik yang usianya antara 4 tahun sampai 6 tahun berada dalam lembaga formal pada tingkat satuan pendidikan Raudlatul Athfal yang selanjutnya disingkat RA setara dengan Taman kanak-kanak pada umumnya adalah salah satu bentuk satuan pendidikan anak usia dini pada jalur pendidikan formal yang menyelenggarakan program pendidikan dengan kekhasan agama Islam bagi anak usia 4 (empat) tahun sampai dengan 6 (enam) tahun. ${ }^{114}$

\section{Manajemen Peserta Didik Raudlatul Athfal}

Manajemen Peserta Didik merupakan penggabungan dari kata manajemen, dan peserta didik. Manajemen sendiri diartikan bermacam-macam sesuai dengan sudut pandang para ahlinya. Secara etimologis, kata manajemen merupakan terjemahan dari kata management (bahasa Inggris). Kata management sendiri berasal dari kata manage atau magiare yang berarti melatih kuda dalam melangkahkan kakinya. Dalam pengertian manajemen, terkandung dua kegiatan,

114 Keputusan Direktur Jendral Pendidikan Islam Nomor 1714 tahun 2015, tentang Pedoman Penerimaan Peserta Didik Baru Tahun 2015-2016, (Jakarta : Pasal 1 ayat 10, 2015), hal. 1 
Fu'ad Arif Noor : Manajemen Peserta Didik Raudlatul Athfal (RA)

yakni kegiatan pikir (mind) dan kegiatan tindak laku (action). 115

Manajemen menurut istilah adalah proses mengoordinasikan aktivitas-aktivitas kerja sehingga dapat selesai secara efisien dan efektif dengan dan melalui orang lain. Dalam Encylopedia of the Social Science dikatakan bahwa manajemen adalah proses pelaksanaan program untuk mencapai tujuan tertentu yang diselenggarakan dan diawasi. Sedangkan G. R. Terry mengatakan bahwa manajemen merupakan proses khas yang terdiri atas tindakan-tindakan perencanaan, pengorganisasian, penggerakan, dan pegendalian yang dilakukan untuk menentukan serta mencapai sasaran yang telah ditentukan melalui pemanfaatan sumber daya manusia dan sumber daya lainnya.116

Ramayulis, menyatakan bahwa pengertian yang sama dengan hakikat manajemen adalah al-tadbir (pengaturan). ${ }^{\mathbf{1 1 7}}$ Kata ini merupakan derivasi dari kata dabbara (mengatur) yang banyak terdapat dalam Al-Qur'an, seperti firman Allah dalam Surat As-Sajdah [32] ayat 5 :

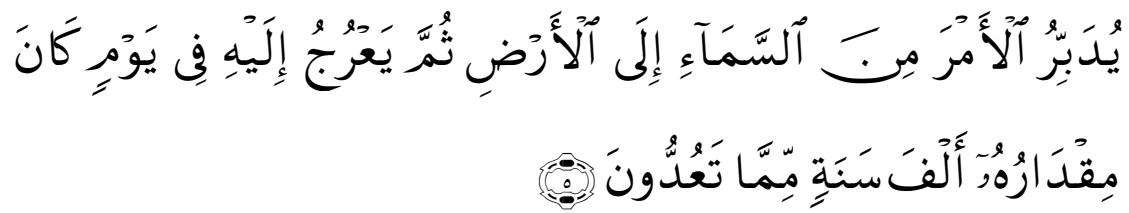

Artinya: "Dia mengatur segala urusan dari langit ke bumi, kemudian (urusan) itu naik kepada-Nya dalam satu hari yang kadarnya (lamanya) adalah seribu tahun menurut perhitunganmu". [Maksud perhitunganmu adalah urusan itu naik kepadanya ialah beritanya yang dibawa oleh malaikat.

115 Saefullah, Manajemen Pendidikan Islam, (Bandung: Pustaka Setia, 2012), hal. 4

116 Ibid., hal. 2-3.

117 Ibid., hal. 1. 
ayat ini suatu tamsil bagi kebesaran Allah dan keagunganNya] (Q.S. As-Sajdah [32] : 5)

Dari beberapa definisi manajemen yang sudah dikemukakan di atas dapat disimpulkan bahwa manajemen adalah ilmu pengetahuan dan seni untuk mengatur, mengoordinasikan, aktivitas kerja dengan cara memanfaatkan orang lain untuk mencapai suatu tujuan tertentu.

Peserta didik, menurut ketentuan umum UndangUndang RI tentang Sistem Pendidikan Nasional adalah anggota masyarakat yang berusaha mengembangkan dirinya melalui proses pendidikan pada jalur, jenjang, dan jenis pendidikan tertentu. Peserta didik juga mempunyai sebutansebutan lain seperti murid, subjek didik, anak didik, pembelajar, dan sebagainya. ${ }^{118}$

Manajemen peserta didik keberadaannya sangat dibutuhkan di Raudlatul Athfal, karena murid merupakan subyek sekaligus obyek dalam proses transformasi ilmu dan ketrampilan. Keberhasilan dalam penyelenggaraan Raudlatul Athfal akan sangat bergantung dengan perkembangan potensi fisik, kecerdasan intelektual, social, emosional dan kejiwaan peserta didik. Manajemen peserta didik merupakan penataan dan pengaturan terhadap kegiatan yang berkaitan dengan peserta didik itu sendiri, mulai dari murid itu masuk sampai dengan keluar atau lulus dari Raudlatul Athfal. Manajemen peserta didik tidak semata-mata pencatatan data peserta didik, akan tetapi meliputi aspek yang lebih luas yaitu

118 Ali Imron, Manajemen Peserta Didik Berbasis Sekolah, (Jakarta: Bumi Aksara, 2011), hal. 5. 
membantu upaya petumbuhan dan perkembangan murid melalui proses pendidikan di Raudlatul Athfal.

Manajemen peserta didik bertujuan mengatur berbagai kegiatan dalam bidang kemuridan agar kegiatan pembelajaran di Raudlatul Athfal berjalan lancar, tertib dan teratur. Beberapa ahli berpendapat bahwa tujuan manajemen peserta didik Raudlatul Athfal adalah untuk menciptakan kondisi lingkungan sekolah yang baik serta agar murid dapat belajar dengan tertib, senang, hati riang gembira sehingga tercapai tujuan pembelajaran yang efektif dan efisien. Ada tiga jenis tugas utama dalam manajemen peserta didik Raudlatul Athfal untuk mencapai tujuan tersebut, yaitu penerimaan peserta didik, kegiatan kemajuan belajar, serta bimbingan dan pembinaan disiplin. 119

\section{Perencanaan}

Perencanaan penerimaan peserta didik baru pada RA bertujuan memberi kesempatan yang seluas-luasnya bagi warga Negara usia sekolah agar memperoleh layanan pendidikan yang sebaik-baiknya secara teertib, terarah, sistematis, transparan dan berkeadilan. Semua anak usia sekolah memiliki kesempatan yang sama untuk memperoleh pendidikan pada satuan pendidikan. Pada dasarnya tidak ada penolakan peserta didik baru, bagi yang memenuhi syarat kecuali jika daya tamping di RA yang bersangkutan tidak mencukupi dan ketentuan waktu proses penerimaan telah bearkhir. (Pasal 2 dan 3) ${ }^{\mathbf{1 2 0}}$

119 Meilina Bustari, Manajemen Peserta Didik, (Yogyakarta : FIP UNY, 2005), hal.12.

120 Keputusan Dirjen Pendis, Op. Cit., hal. 3 
Calon peserta didik baru RA dengan syarat sebagai berikut :

1. Usia 4 tahum sampai dengan 5 tahun untuk kelompok A;

2. Usia 5 tahun sampai dengan 6 tahun untuk kelompok B;

3. Memiliki Akte Kelahiran/Surat Keterangan Lahir;

4. Kelompok A, dan B, bukan merupakan jenjang belajar, melainkan semata-mata pengelompokkan belajar yang berdasarkan pada kelompok usia anak.121

Sedangkan prinsip penerimaan peserta didik baru adalah : Semua anak usia sekolah memiliki kesempatan yang sama untuk memperoleh pendidikan pada satuan pendidikan yang lebih tinggi; Tidak ada penolakan Penerimaan Peserta Didik Baru (PPDB) bagi yang memenuhi syarat kecuali jika daya tampung di madrasah dan ketentuan waktu proses PPDB telah berakhir; Sejak awal pendaftaran calon peserta didik dapat menentukan pilihannya ke madrasah negeri atau madrasah swasta.

Penerimaan peserta didik ini berasaskan pada yang pertama : objektif, artinya bahwa penerimaan maupun pindahan harus memenuhi persyaratan dan ketentuan yang telah ditetapkan. Kedua : Transparan, artinya penerimaan peserta didik baru bersifat terbuka dan dapat diketahui oleh masyarakat termasuk orang tua peserta didik dan stackholder pendidikan. Ketiga : Akuntabel, artinya penerimaan peserta didik baru dapat dipertanggungjawabkan baik prosedur, hasil maupun aspek pendanaannya. Keempat : Tidak Diskriminatif, artinya tanpa membedakan suku, ras, golongan dan status social ekonomi masyarakat. Dan yang kelima : Kompetitif, 
artinya dilakukan melalui seleksi berdasarkan kompetensi yang disyaratkan oleh satuan pendidikan tertentu. ${ }^{\mathbf{1 2 2}}$

Proses penerimaan peserta didik baru menjadi hal yang rutin selalu dilakukan oleh penyelenggara pendidikan pada setiap awal tahun pelajaran sebagai proses awal pendataan dan seleksi peserta didik yang akan masuk pada tahun pelajaran baru. Dalam upaya peningkatan akses pelayanan pendidikan, jumlah peserta didik baru yang dapat diterima pada RA dalam satu rombongan belajar/kelas paling banyak 25 (dua puluh lima) orang. ${ }^{123}$

\section{Pembinaan}

Peserta didik RA dalam pembinaannya termasuk anak dalam rentan usia 4 (empat) tahun sampai dengan 6 (enam) tahun yang tingkat pencapaian perkembangannya meliputi nilai agama dan Moral, Fisik motorik kasar dan halus, kesehatan dan prilaku keselamatan, kognitif yang terdiri dari belajar dan pemecahan masalah, serta berfikir logis dan simbolik. Untuk bahasa meliputi memahami bahasa, mengungkapkan bahasa, dan keaksaraan. Selanjutnya lingkup sosial emosional anak meliputi kesadaran diri, rasa tanggungjawab untuk diri sendiri dan orang lain, serta perilaku prososial. Sedangkan lingkup perkembangan yang terakhir mencakup seni yang meliputi anak mampu menikmati berbagai alunan lagu atau suara dan tertarik dengan kegiatan seni. Berikut tabel Tingkat Pencapaian Perkembangan Peserta Didik RA usia 4 - 6 tahun :124

122 Ibid., hal. 3.

123 Ibid., hal. 12.

124 Peraturan Menteri Pendidikan dan Kebudayaan RI, Nomor : 137 Tahun 2014, Lampiran 1 Tentang Standar Nasional Pendidikan Anak Usia 


\begin{tabular}{|c|c|}
\hline \multicolumn{2}{|c|}{$\begin{array}{l}\text { Lingkup Perkembangan : } \\
\text { I. Nilai Agama dan Moral }\end{array}$} \\
\hline \multicolumn{2}{|c|}{ Tingkat Pencapaian Perkembangan Anak } \\
\hline Usia 4 - 5 tahun & Usia 5 - 6 tahun \\
\hline $\begin{array}{l}\text { 1. Mengetahui agama yang } \\
\text { dianutnya }\end{array}$ & $\begin{array}{l}\text { 1. Mengenal agama yang } \\
\text { dianut }\end{array}$ \\
\hline $\begin{array}{l}\text { 2. Meniru gerakan beribadah } \\
\text { dengan urutan yang benar }\end{array}$ & 2. Mengerjakan ibadah \\
\hline $\begin{array}{l}\text { 3. Mengucapkan doa sebelum } \\
\text { dan/atau sesudah } \\
\text { melakukan sesuatu }\end{array}$ & $\begin{array}{l}\text { 3. Berperilaku jujur, } \\
\text { penolong, sopan, hormat, } \\
\text { sportif, dsb }\end{array}$ \\
\hline $\begin{array}{l}\text { 4. Mengenal perilaku } \\
\text { baik/sopan dan buruk }\end{array}$ & $\begin{array}{l}\text { 4. Menjaga kebersihan diri } \\
\text { dan lingkungan }\end{array}$ \\
\hline $\begin{array}{l}\text { 5. Membiasakan diri } \\
\text { berperilaku baik }\end{array}$ & $\begin{array}{l}\text { 5. Mengetahui hari besar } \\
\text { agama }\end{array}$ \\
\hline $\begin{array}{l}\text { 6. Mengucapkan salam dan } \\
\text { membalas salam }\end{array}$ & $\begin{array}{l}\text { 6. Menghormati (toleransi) } \\
\text { agama orang lain }\end{array}$ \\
\hline \multicolumn{2}{|l|}{$\begin{array}{l}\text { II. Fisik Motorik } \\
\text { A. Motorik Kasar }\end{array}$} \\
\hline $\begin{array}{l}\text { 1. Menirukan gerakan } \\
\text { binatang, pohon tertiup } \\
\text { angin, pesawat terbang, } \\
\text { dsb } \\
\text { 2. Melakukan gerakan } \\
\text { menggantung (bergelayut) }\end{array}$ & $\begin{array}{l}\text { 1. Melakukan gerakan } \\
\text { tubuh secara } \\
\text { terkoordinasi untuk } \\
\text { melatih kelenturan, } \\
\text { keseimbangan, dan } \\
\text { kelincahan }\end{array}$ \\
\hline $\begin{array}{l}\text { 3. Melakukan gerakan } \\
\text { melompat, meloncat, dan } \\
\text { berlari secara terkoordinasi } \\
\text { 4. Melempar sesuatu secara } \\
\text { terarah }\end{array}$ & $\begin{array}{l}\text { 2. Melakukan koordinasi } \\
\text { gerakan mata-kaki- } \\
\text { tangan-kepala dalam } \\
\text { menirukan tarian atau } \\
\text { senam }\end{array}$ \\
\hline $\begin{array}{l}\text { 5. Menangkap sesuatu secara } \\
\text { tepat }\end{array}$ & $\begin{array}{l}\text { 3. Melakukan permainan } \\
\text { fisik dengan aturan }\end{array}$ \\
\hline $\begin{array}{l}\text { 6. Melakukan gerakan } \\
\text { antisipasi }\end{array}$ & $\begin{array}{l}\text { 4. Terampil menggunakan } \\
\text { tangan kanan dan kiri }\end{array}$ \\
\hline $\begin{array}{l}\text { 7. Menendang sesuatu secara } \\
\text { terarah }\end{array}$ & $\begin{array}{l}\text { 5. Melakukan kegiatan } \\
\text { kebersihan diri. }\end{array}$ \\
\hline
\end{tabular}

Dini, (Jakarta : 2014), hal. 21-31. 
8. Memanfaatkan alat permainan di luar kelas.

\section{B. Motorik Halus}

1. Membuat garis vertikal, horizontal, lengkung kiri/kanan, miring kiri/kanan, dan lingkaran

2. Menjiplak bentuk

3. Mengkoordinasikan mata dan tangan untuk melakukan gerakan yang rumit

4. Melakukan gerakan manipulatif untuk menghasilkan suatu bentuk dengan menggunakan berbagai media

5. Mengekspresikan diri dengan berkarya seni menggunakan berbagai media

6. Mengontrol gerakan tangan yang menggunakan otot halus (menjumput, mengelus, mencolek, mengepal, memelintir, memilin, memeras).

C. Kesehatan dan Perilaku Keselamatan

1. Berat badan sesuai tingkat usia

2. Tinggi badan sesuai tingkat usia

3. Berat badan sesuai dengan standar tinggi badan

4. Lingkar kepala sesuai tingkat usia

5. Menggunakan toilet (penggunaan air,
1. Menggambar sesuai gagasannya

2. Meniru bentuk

3. Melakukan eksplorasi dengan berbagai media dan kegiatan

4. Menggunakan alat tulis dan alat makan dengan benar

5. Menggunting sesuai dengan pola

6. Menempel gambar dengan tepat

7. Mengekspresikan diri melalui gerakan menggambar secara rinci.

1. Berat badan sesuai tingkat usia

2. Tinggi badan sesuai standar usia

3. Berat badan sesuai dengan standar tinggi badan

4. Lingkar kepala sesuai tingkat usia

5. Menutup hidung dan 


\begin{tabular}{|c|c|}
\hline $\begin{array}{l}\text { membersihkan diri) dengan } \\
\text { bantuan minimal } \\
\text { 6. Memahami berbagai alarm } \\
\text { bahaya (kebakaran, banjir, } \\
\text { gempa) } \\
\text { 7. Mengenal rambu lalu lintas } \\
\text { yang ada di jalan. }\end{array}$ & $\begin{array}{l}\text { mulut (misal, ketika } \\
\text { batuk dan bersin) } \\
\text { 6. Membersihkan, dan } \\
\text { membereskan tempat } \\
\text { bermain } \\
\text { 7. Mengetahui situasi yang } \\
\text { membahayakan diri } \\
\text { 8. Memahami tata cara } \\
\text { menyebrang } \\
\text { 9. Mengenal kebiasaan } \\
\text { buruk bagi kesehatan } \\
\text { (rokok, minuman keras). }\end{array}$ \\
\hline \multicolumn{2}{|c|}{$\begin{array}{l}\text { III. Kognitif } \\
\text { A. Belajar dan Pemecahan Masalah }\end{array}$} \\
\hline $\begin{array}{l}\text { 1. Mengenal benda } \\
\text { berdasarkan fungsi (pisau } \\
\text { untuk memotong, pensil } \\
\text { untuk menulis) } \\
\text { 2. Menggunakan benda-benda } \\
\text { sebagai permainan simbolik } \\
\text { (kursi sebagai mobil) } \\
\text { 3. Mengenal konsep } \\
\text { sederhana dalam } \\
\text { kehidupan sehari-hari } \\
\text { (gerimis, hujan, gelap, } \\
\text { terang, temaram, dsb) } \\
\text { 4. Mengetahui konsep banyak } \\
\text { dan sedikit } \\
\text { 5. Mengkreasikan sesuatu } \\
\text { sesuai dengan idenya } \\
\text { sendiri yang terkait dengan } \\
\text { berbagai pemecahan } \\
\text { masalah } \\
\text { Mengamati benda dan } \\
\text { gejala dengan rasa ingin } \\
\text { tahu } \\
\text { Mengenal pola kegiatan dan } \\
\text { menyadari pentingnya }\end{array}$ & $\begin{array}{l}\text { 1. Menunjukkan aktivitas } \\
\text { yang bersifat eksploratif } \\
\text { dan menyelidik (seperti: } \\
\text { apa yang terjadi ketika air } \\
\text { ditumpahkan) } \\
\text { 2. Memecahkan masalah } \\
\text { sederhana dalam } \\
\text { kehidupan sehari-hari } \\
\text { dengan cara yang } \\
\text { fleksibel dan diterima } \\
\text { sosial } \\
\text { Menerapkan pengetahuan } \\
\text { atau pengalaman dalam } \\
\text { konteks yang baru } \\
\text { Menunjukkan sikap } \\
\text { kreatif dalam } \\
\text { menyelesaikan masalah } \\
\text { (ide, gagasan di luar } \\
\text { kebiasaan). }\end{array}$ \\
\hline
\end{tabular}




\section{waktu}

8. Memahami

posisi/kedudukan dalam

keluarga, ruang,

lingkungan sosial (misal:

sebagai peserta

didik/anak/teman)

\section{B. Berfikir Logis}

1. Mengklasifikasikan benda berdasarkan fungsi, bentuk atau warna atau ukuran

2. Mengenal gejala sebabakibat yang terkait dengan dirinya

3. Mengklasifikasikan benda ke dalam kelompok yang sama atau kelompok yang sejenis atau kelompok yang berpasangan dengan 2 variasi

4. Mengenal pola (misal, AB$\mathrm{AB}$ dan $\mathrm{ABC}-\mathrm{ABC}$ ) dan mengulanginya

5. Mengurutkan benda berdasarkan 5 seriasi ukuran atau warna
1. Mengenal perbedaan berdasarkan ukuran: "lebih dari"; "kurang dari"; dan "paling/ter"

2. Menunjukkan inisiatif alam memilih tema permainan (seperti: "ayo kita bermain pura-pura seperti burung")

3. Menyusun perencanaan kegiatan yang akan dilakukan

4. Mengenal sebab-akibat tentang lingkungannya (angin bertiupmenyebabkan daun bergerak, air dapat menyebabkan sesuatu menjadi basah)

5. Mengklasifikasikan benda berdasarkan warna, bentuk, dan ukuran (3 variasi)

6. Mengklasifikasikan benda yang lebih banyak ke dalam kelompok yang sama atau kelompok yang sejenis, atau kelompok berpasangan yang lebih dari 2 variasi 


\begin{tabular}{|c|c|}
\hline & $\begin{array}{l}\text { 7. Mengenal pola ABCD- } \\
\text { ABCD } \\
\text { 8. Mengurutkan benda } \\
\text { berdasarkan ukuran dari } \\
\text { paling kecil ke paling } \\
\text { besar atau sebaliknya }\end{array}$ \\
\hline \multicolumn{2}{|l|}{ C. Berfikir Simbolik } \\
\hline $\begin{array}{l}\text { 1. Membilang banyak benda } \\
\text { satu sampai sepuluh } \\
\text { 2. Mengenal konsep bilangan } \\
\text { 3. Mengenal lambang bilangan } \\
\text { 4. Mengenal lambang huruf }\end{array}$ & $\begin{array}{l}\text { 1. Menyebutkan lambang } \\
\text { bilangan 1-10 } \\
\text { 2. Menggunakan lambang } \\
\text { bilangan untuk } \\
\text { menghitung } \\
\text { 3. Mencocokkan bilangan } \\
\text { dengan lambang bilangan } \\
\text { 4. Mengenal berbagai } \\
\text { macam lambang huruf } \\
\text { vokal dan konsonan } \\
\text { Merepresentasikan } \\
\text { berbagai macam benda } \\
\text { dalam bentuk gambar } \\
\text { atau tulisan (ada benda } \\
\text { pensil yang diikuti tulisan } \\
\text { dan gambar pensil) }\end{array}$ \\
\hline \multicolumn{2}{|l|}{$\begin{array}{l}\text { IV. Bahasa } \\
\text { A. Memahami bahasa }\end{array}$} \\
\hline $\begin{array}{l}\text { 1. Menyimak perkataan orang } \\
\text { lain } \\
\text { (bahasa ibu atau bahasa } \\
\text { lainnya) } \\
\text { 2. Mengerti dua perintah yang } \\
\text { diberikan bersamaan } \\
\text { 3. Memahami cerita yang } \\
\text { dibacakan } \\
\text { 4. Mengenal perbendaharaan } \\
\text { kata mengenai kata sifat } \\
\text { (nakal, pelit, baik hati, } \\
\text { berani, baik, jelek, dsb) } \\
\text { Mendengar dan }\end{array}$ & $\begin{array}{l}\text { 1. Mengerti beberapa } \\
\text { perintah secara } \\
\text { bersamaan } \\
\text { 2. Mengulang kalimat yang } \\
\text { lebih kompleks } \\
\text { 3. Memahami aturan dalam } \\
\text { suatu permainan } \\
\text { 4. Senang dan menghargai } \\
\text { bacaan }\end{array}$ \\
\hline
\end{tabular}




\begin{tabular}{|c|c|}
\hline $\begin{array}{l}\text { membedakan bunyi- } \\
\text { bunyian dalam Bahasa } \\
\text { Indonesia (contoh, bunyi } \\
\text { dan ucapan harus sama) }\end{array}$ & \\
\hline \multicolumn{2}{|l|}{ B. Mengungkapkan Bahasa } \\
\hline $\begin{array}{l}\text { 1. Mengulang kalimat } \\
\text { sederhana }\end{array}$ & $\begin{array}{l}\text { 1. Menjawab pertanyaan } \\
\text { yang lebih kompleks }\end{array}$ \\
\hline $\begin{array}{l}\text { 2. Bertanya dengan kalimat } \\
\text { yang benar }\end{array}$ & $\begin{array}{l}\text { 2. Menyebutkan kelompok } \\
\text { gambar yang memiliki }\end{array}$ \\
\hline $\begin{array}{l}\text { 3. Menjawab pertanyaan } \\
\text { sesuai pertanyaan }\end{array}$ & $\begin{array}{l}\text { bunyi yang sama } \\
\text { 3. Berkomunikasi secara }\end{array}$ \\
\hline $\begin{array}{l}\text { 4. Mengungkapkan perasaan } \\
\text { dengan kata sifat (baik, } \\
\text { senang, nakal, pelit, baik } \\
\text { hati, berani, baik, jelek, } \\
\text { dsb) }\end{array}$ & $\begin{array}{l}\text { lisan, memiliki } \\
\text { perbendaharaan kata, } \\
\text { serta mengenal simbol- } \\
\text { simbol untuk persiapan } \\
\text { membaca, menulis dan }\end{array}$ \\
\hline 5. Menyebutkan kata-kata & berhitung \\
\hline $\begin{array}{l}\text { yang dikenal } \\
\text { 6. Mengutarakan pendapat } \\
\text { kepada } \\
\text { orang lain }\end{array}$ & $\begin{array}{l}\text { 4. Menyusun kalimat } \\
\text { sederhana dalam struktur } \\
\text { lengkap (pokok kalimat- } \\
\text { predikat-keterangan) }\end{array}$ \\
\hline $\begin{array}{l}\text { 7. Menyatakan alasan } \\
\text { terhadap sesuatu yang } \\
\text { diinginkan atau } \\
\text { ketidaksetujuan }\end{array}$ & $\begin{array}{l}\text { 5. Memiliki lebih banyak } \\
\text { kata-kata untuk } \\
\text { mengekpresikan ide pada } \\
\text { orang lain }\end{array}$ \\
\hline $\begin{array}{l}\text { 8. Menceritakan kembali } \\
\text { cerita/dongeng yang } \\
\text { pernah didengar }\end{array}$ & $\begin{array}{l}\text { 6. Melanjutkan sebagian } \\
\text { cerita/dongeng yang telah } \\
\text { diperdengarkan }\end{array}$ \\
\hline $\begin{array}{l}\text { 9. Memperkaya } \\
\text { perbendaharaan kata }\end{array}$ & $\begin{array}{l}\text { 7. Menunjukkkan } \\
\text { pemahaman konsep- }\end{array}$ \\
\hline $\begin{array}{l}\text { 10. Berpartisipasi dalam } \\
\text { percakapan }\end{array}$ & konsep dalam buku cerita \\
\hline \multicolumn{2}{|l|}{ C. Keaksaraan } \\
\hline $\begin{array}{l}\text { 1. Mengenal simbol-simbol } \\
\text { 2. Mengenal suara-suara } \\
\text { hewan/benda yang ada di } \\
\text { sekitarnya } \\
\text { 3. Membuat coretan yang }\end{array}$ & $\begin{array}{l}\text { 1. Menyebutkan simbol- } \\
\text { simbol huruf yang dikenal } \\
\text { 2. Mengenal suara huruf } \\
\text { awal dari nama benda- } \\
\text { benda yang ada di }\end{array}$ \\
\hline
\end{tabular}




\begin{tabular}{|c|c|}
\hline $\begin{array}{l}\text { bermakna } \\
\text { 4. Meniru (menuliskan dan } \\
\text { mengucapkan) huruf A-Z }\end{array}$ & $\begin{array}{l}\text { sekitarnya } \\
\text { 3. Menyebutkan kelompok } \\
\text { gambar yang memiliki } \\
\text { bunyi/huruf awal yang } \\
\text { sama. } \\
\text { 4. Memahami hubungan } \\
\text { antara bunyi dan bentuk } \\
\text { huruf } \\
\text { 5. Membaca nama sendiri } \\
\text { 6. Menuliskan nama sendiri } \\
\text { 7. Memahami arti kata } \\
\text { dalam cerita }\end{array}$ \\
\hline \multicolumn{2}{|l|}{$\begin{array}{l}\text { V. Sosial-emosional } \\
\text { A. Kesadaran Diri }\end{array}$} \\
\hline $\begin{array}{l}\text { 1. Menunjukkan sikap } \\
\text { mandiri dalam memilih } \\
\text { kegiatan } \\
\text { 2. Mengendalikan perasaan } \\
\text { 3. Menunjukkan rasa percaya } \\
\text { diri } \\
\text { 4. Memahami peraturan dan } \\
\text { disiplin } \\
\text { 5. Memiliki sikap gigih (tidak } \\
\text { mudah menyerah) } \\
\text { 6. Bangga terhadap hasil } \\
\text { karya sendiri }\end{array}$ & 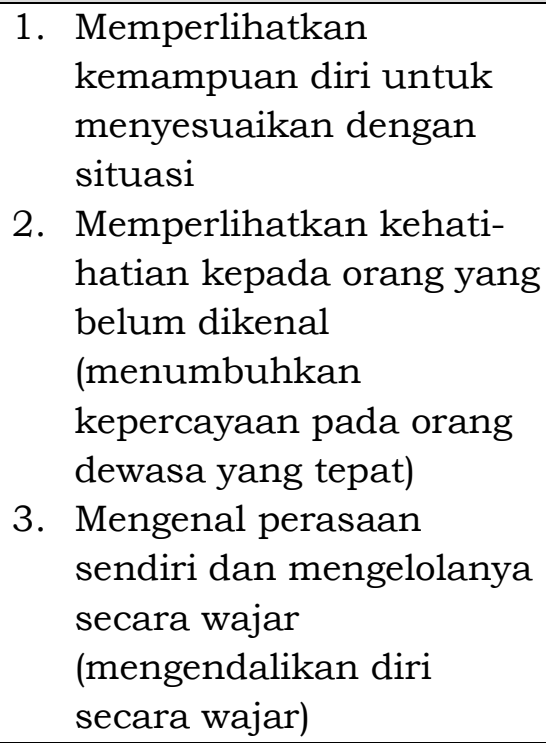 \\
\hline \multicolumn{2}{|c|}{ B. Rasa tanggung jawab untuk diri sendiri dan orang lain } \\
\hline $\begin{array}{l}\text { 1. Menjaga diri sendiri dari } \\
\text { lingkungannya } \\
\text { 2. Menghargai keunggulan } \\
\text { orang lain } \\
\text { 3. Mau berbagi, menolong, } \\
\text { dan membantu teman }\end{array}$ & $\begin{array}{l}\text { 1. Tahu akan hak nya } \\
\text { 2. Mentaati aturan kelas } \\
\text { (kegiatan, aturan) } \\
\text { 3. Mengatur diri sendiri } \\
\text { 4. Bertanggung jawab atas } \\
\text { perilakunya untuk } \\
\text { kebaikan diri sendiri }\end{array}$ \\
\hline
\end{tabular}




\section{Perilaku Prososial}

1. Menunjukan antusiasme dalam melakukan permainan

2. Menaati aturan yang berlaku dalam suatu permainan

3. Menghargai orang lain

4. Menunjukkan rasa empati kompetitif secara positif

VI. Seni

\section{A. Anak mampu menikmati berbagai alunan lagu atau suara}

1. Senang mendengarkan berbagai macam musik atau lagu kesukaannya

2. Memainkan alat musik/instrumen/benda yang dapat membentuk irama yang teratur
1. Bermain dengan teman sebaya

2. Mengetahui perasaan temannya dan merespon secara wajar

3. Menghargai hak/pendapat/karya orang lain

4. Menggunakan cara yang diterima secara sosial dalam menyelesaikan masalah (menggunakan fikiran untuk menyelesaikan masalah)

5. Bersikap kooperatif dengan teman

6. Menunjukkan sikap toleran

7. Mengekspresikan emosi yang sesuai dengan kondisi yang ada (senangsedih-antusias dsb)

8. Mengenal tata krama dan sopan santun sesuai dengan nilai sosial budaya setempat

9. Berbagi dengan orang lain
1. Anak bersenandung atau bernyanyi sambil mengerjakan sesuatu

2. Memainkan alat musik/instrumen/benda bersama teman 


\section{B. Tertarik dengan kegiatan seni}

1. Memilih jenis lagu yang disukai

2. Bernyanyi sendiri

3. Menggunakan imajinasi untuk mencerminkan perasaan dalam sebuah peran

4. Membedakan peran fantasi dan kenyataan

5. Menggunakan dialog, perilaku, dan berbagai materi dalam menceritakan suatu cerita

6. Mengekspresikan gerakan dengan irama yang bervariasi

7. Menggambar objek di sekitarnya

8. Membentuk berdasarkan objek yang dilihatnya (mis. dengan plastisin, tanah liat)

9. Mendeskripsikan sesuatu (seperti binatang) dengan ekspresif yang berirama (contoh, anak menceritakan gajah dengan gerak dan mimik tertentu)

10. Mengkombinasikan berbagai warna ketika menggambar atau mewarnai
1. Menyanyikan lagu dengan sikap yang benar

2. Menggunakan berbagai macam alat musik tradisional maupun alat musik lain untuk menirukan suatu irama atau lagu tertentu

3. Bermain drama sederhana

4. Menggambar berbagai macam bentuk yang beragam

5. Melukis dengan berbagai cara dan objek

6. Membuat karya seperti bentuk sesungguhnya dengan berbagai bahan (kertas, plastisin, balok, d11)

Sumber: Peraturan Menteri Pendidikan dan Kebudayaan RI Nomor : 137 Tahun 2014 Tentang Standar Nasional Pendidikan Anak Usia Dini 
Fu'ad Arif Noor : Manajemen Peserta Didik Raudlatul Athfal (RA)

\section{Evaluasi}

Evaluasi peserta didik RA termasuk hasil belajarnya perlu dilakukan agar diketahui perkembangan mereka dari waktu ke waktu. Evaluasi hasil belajar peserta didik dimaksudkan untuk mengetahui sejauh mana peserta didik telah dapat menampilkan performa sebagaimana yang dikehendaki sesuai yang diharapkan. Tanggungjawab untuk mengevaluasi belajar peserta didik berada di tangan pendidik. Evaluasi merupakan pengumpulan informasi untuk menentukan kualitas dan kuantitas belajar peserta didik. 125

Penilaian merupakan serangkaian kegiatan untuk memperoleh, menganalisis dan menafsirkan data tentang proses dan hasil belajar peserta didik yang dilakukan secara sistematis dan berkesinambungan, sehingga menjadi informasi yang bermakna dalam pengambilan keputusan. Jadi, evaluasi adalah suatu usaha yang dilakukan untuk mendapatkan informasi secara sistematis dan berkesinambungan serta menyeluruh tentang proses dan hasil belajar peserta didik sehingga dapat dijadikan informasi dan patokan dalam pengambilan sebuah keptusan mengenai tuntas tidaknya, paham atau tidak paham siswa dalam proses pembelajaran.

Pengetahuan mengenai peserta didik demikian, dimaksudkan untuk mengambil keputusan-keputusan penting mengenai peserta didik, apakah perlu diberi pengayaan, nasehat, bimbingan, penyuluhan, dipromosikan, dinaikkan kelas, diluluskan, dimutasikan, dan sebagainya.

125 Trianto, Desain Pengembangan Pembelajaran Tematik Bagi Anak Usia Dini TK/RA \& Anak Usia Kelas Awal SD/MI, (Jakarta : Kencana Prenada Media Group, 2011), hal. 87. 
Dengan kata lain dengan adanya evaluasi akan dapat diambil langkah-langkah penting yang berkaitan dengan peserta didik. Agar evaluasi dapat mencapai sasarannya, para pendidik perlu memedomani prinsip dan menerapkan tekniktekniknya. ${ }^{126}$

Secara garis besar, teknik evaluasi dapat dibedakan menjadi dua golongan besar, yakni teknik tes dan teknik nontes. Segala jenis teknik evaluasi yang tidak dapat digolongkan ke dalam tes, dapat dikategorikan menjadi teknik nontes.

Pengertian tes secara harfiah adalah tes berasal dari bahsa perancis kuno: testum dengan arti piring untuk menyisihkan logam-logam mulia ,maksudnya dengan menggunakan alat berupa piring itu akan dapat di peroleh jenis logam akan dapat di peroleh logam yang sangat tinggi nilainya. Dalam bahasa inggris di tulis dengan test : yang dalam bahasa indonesia diartikan tes,ujian atau percobaan. Sedangkan dalam bahsa arab imtihan.

Menurut istilah test adalah alat atau prosedur yang di gunakan dalam rangka pengukuran dan penilaian, testing berarti saat di laksanakannya atau peristiwa berlangsungnya pengukuran dan penilaian, tester artinya orang yang melaksanakan tes atau pembuat tes atau eksperimentor yaitu orang yang sedang melakukan percobaan.

Menurut Anne Anastasi dalam psycological testing yang dimaksud dengan tes adalah alat pengukur yang mempunyai standar yang objektif sehingga dapat digunakan secara luas, serta dapat di gunakan untuk mengukur dan

126 Ali Imron, Op.Cit., hal. 116-120. 
membandingkan keadaan psikis atau tingkah laku individu. Menurut Lee $\mathrm{J}$ Cronbach dalam essential of psikologycal testing tes merupakan suatu prosedur yang sistematis utnuk membandingkan tingkah laku dua orang atau lebih.

Wayan Nurkencana (1993), tes adalah suatu cara untuk mengadakan penilaian yang berbentuk suatu tugas yang harus dikerjakan anak atau sekelompok anak sehingga menghasilkan suatu nilai tentang tingkah laku atau prestasi anak tersebut yang kemudian dapat dibandingkan dengan nilai yang dicapai oleh anak-anak lain atau standar yang telah ditetapkan. Jadi kesimpulannya test itu merupakan suatu cara untuk menilai satu orang atau lebih baik dari segi psikis maupun psikologisnya yang mempunyai cara-cara yang sistematis.

Metode tes digunakan dengan alat penilaian berbentuk tes. Karena berbagai pertimbangan antara lain tujuan kegiatan peserta didik RA, metode tes jarang sekali digunakan. Namun tidak tertutup kemungkinan guru menggunakan metode tes ini. Terdapat dua jenis tes, yaitu tes standar dan tes buatan guru. Tes standar terdiri dari tes intelegensi, minat, bakat kepribadian atau yang lainnya. Tes itu dihasilkan melalui prosedur yang panjang. Penggunaan tes standard tersebut hanya oleh orang-orang yang memiliki kualifikasi yang dituntut dalam penggunaan tes itu. Kalau guru ingin mengetahui potensi yang berhubungan dengan intelegensi atau lainnya itu, guru harus meminta bantuan ahlinya (psikolog anak). Guru hanya menggunakan hasil tes untuk lebih mengenali anak.

Tes buatan guru dapat dihasilkan oleh guru, termasuk 
guru RA. Menurut Soemiartini (2000) dalam mengembangkan tes ini, guru harus memilih secara cermat butir-butir pertanyaan yang berkaitan dengan tujuan yang hendak dicapai. Selain tes, metode penilaian yang lain adalah non tes. Metode ini digunakan dengan bantuan alat-alat penilaian non tes. Alat penilaian non tes banyak jenisnya yang sering digunakan di RA antara lain terdiri dari pemberian tugas, percakapan, observasi, portofolio dan penilaian diri sendiri. ${ }^{\mathbf{1 2 7}}$ 1. Pemberian Tugas

Pemberian tugas adalah suatu cara penilaian yang dilakukan dengan memberikan tugas-tugas tertentu sesuai dengan kemampuan yang akan diungkap. Penilaian dengan cara ini dapat digunakan dengan cara melihat hasil kerja anak dan cara anak mengerjakan tugas tersebut. Pemberian tugas sebagai alat penilaian dapat diselesaikan secara kelompok, berpasangan atau individual. Data penilaian yang diperoleh melalui pemberian tugas dapat direkam dengan menggunakan format tugas, daftar cek, dan skala penilaian. Contoh membentuk dengan tanah liat atau plastisin.

2. Percakapan

Percakapan adalah penilaian yang dilakukan melalui percakapan atau cerita antara anak dan guru atau antara anak dengan anak. Percakapan dalam rangka penilaian dapat dilakukan guru dengan sengaja dan topic yang dibicarakan juga sesuai dengan tema pelaksana kegiatan pada saat itu. Ada dua macam percakaan dalam rangka

127 Daryanto, Evaluasi Pendidikan. (Jakarta : Rineka Cipta, 2007), hal. $56-58$ 
penilaian yang dapat dilakukan, yaitu pertama penilaian percakapan yang berstruktur dimana percakapan dilakukan dengan sengaja oleh guru dengan menggnakan waktu khusus dan menggnakan pedoman walau sederhana contoh pada berdo'a. Sedangkan yang kedua penilaian percakapan yang tidak berstruktur dimana percakapan dilakukan antara guru dan anak tanpa persiapan, dimana saja, kapan saja, dan sedang melakkan kegiatan lain contoh mengucapkan salam pada saat bertemu.

3. Observasi (Pengamatan)

Observasi atau pengamatan merupakan alat pengumpulan data nilai yang dilakukan dengan merekam/mencatat secara sistematik gejala-gejala tingkah laku yang tampak. Pada dasarnya pengamatan dapat dilakukan setiap waktu dan siapa saja, sehinggah ada orang yang menyatakan bahwa pengamatan merupakan salah satu teknik penilaian yang sederhana dan tidak memerlukan keahlian yang luar biasa. Namun untuk memperoleh hasil yang tepat (objektif) pengamatan perlu direncanakan sedemikian rupa.

4. Catatan anekdot

Catatan anekdot merupakan salah satu bentuk pencatatan tentang gejala tingkah laku yang berkaitan dengan sikap dan perilaku anak yang khusus, baik yang positif maupun yang negative. Catatan anekdot cocok digunakan sebagai alat bantu pencatatan hasil pengamatan. Hal-hal yang dicatat daam anekdot dapat 
meliputi prestasi yang ditunjukkan anak baik berupa karya atau sikap dan perilaku.

5. Skala penilaian

Skala penilaian juga sering digunakan untuk pencatatan hasil pengamatan. Skala penilaian memuat daftar kata-kata atau pernyataan mengenai tingkah laku, sikap, dan atau kemampuan siswa. Skala penilaian ada yang berbentuk bilangan, huruf, dan ada yang berbentuk uraian.

Contoh : Aktivitas belajar anak 12345 Angka 1 bisa berarti sangat rendah, 2 rendah, 3 sedang, 4 tinggi dan 5 sangat tinggi.

6. Unjuk kerja

Unjuk kerja merupakan penilaian yang menuntut peserta didik untuk melakukan tugas dalam perbuatan yang dapat diamati, misalnya praktek menyanyi, mewarnai, meronce, menggambar, menempel, dan lainlain.

7. Hasil Karya

Hasil karya adalah hasil kerja peserta didik setelah melakukan suatu kegiatan dapat berupa pekerjaan tangan atau karya seni.

8. Pengembangan perangkat penilaian sendiri

Guru diperbolehkan untuk mengembangkan perangkat evaluasi atau assesment sendiri sesuai dengan kebutuhan.

9. Penggunaan instrumen standar

Penilaian dengan teknik ini biasanya di tujukan untuk anak yang memerlukan penanganan khusus, 
namun teknik ini harus melibatkan orang yang ahli dalam bidang permasalahan khusus tersebut. ${ }^{128}$

\section{Kesimpulan}

Berdasarkan uraian pembahasan dan analisis di atas, dapat disimpulkan beberapa hal, yaitu bahwa :

1. Tujuan dari penerimaan peserta didik baru RA adalah memberikan layanan bagi anak usia sekolah/lulusan untuk memasuki satuan pendidikan yang lebih tinggi secara tertib dan berkualitas. Sedangkan prinsip penerimaan peserta didik baru adalah :

a. Semua anak usia sekolah memiliki kesempatan yang sama untuk memperoleh pendidikan pada satuan pendidikan yang lebih tinggi;

b. Tidak ada penolakan Penerimaan Peserta Didik Baru (PPDB) bagi yang memenuhi syarat kecuali jika daya tampung di RA dan ketentuan waktu proses PPDB telah berakhir;

c. Sejak awal pendaftaran calon peserta didik dapat menentukan pilihannya ke madrasah negeri atau madrasah swasta.

2. Pelaksanaan penerimaan peserta didik baru RA diharapkan dapat dilaksanakan secara obyektif, transparan, akuntabel, kompetitif dan tidak diskriminatif sehingga masyarakat/orang tua yang menyekolahkan anaknya ke madrasah dapat terlayani dengan baik. Hal ini sesuai dengan Undang-Undang No. 20 Tahun 2003 tentang Sistem Pendidikan Nasional BAB

128 Nenny Mahyuddin, Asesment Anak Usia Dini. (Padang : UNP Press, 2008), hal. 46. 
III Pasal 4 ayat 1 mengatakan pendidikan diselenggarakan secara demokratis dan berkeadilan serta tidak diskriminatif dengan menjunjung tinggi hak asasi manusia, nilai keagamaan, nilai kultural dan kemajemukan bangsa.

3. Manajemen peserta didik dapat diartikan sebagai usaha pengaturan terhadap peserta didik mulai dari peserta didik tersebut masuk sekolah sampai dengan mereka lulus sekolah. Knezevich (1961) mengartikan manajemen peserta didik atau pupil personnel administration sebagai suatu layanan yang memusatkan perhatian pada pengaturan, pengawasan dan layanan siswa di kelas dan di luar kelas seperti: pengenalan, pendaftaran, layanan individual seperti pengembangan keseluruhan kemampuan, minat, kebutuhan sampai ia matang di sekolah.

4. Tingkat pencapaian perkembangan peserta didik RA meliputi nilai agama dan Moral, Fisik motorik kasar dan halus, kesehatan dan prilaku keselamatan, kognitif yang terdiri dari belajar dan pemecahan masalah, serta berfikir logis dan simbolik. Untuk bahasa meliputi memahami bahasa, mengungkapkan bahasa, dan keaksaraan. Selanjutnya lingkup sosial emosional anak meliputi kesadaran diri, rasa tanggungjawab untuk diri sendiri dan orang lain, serta perilaku prososial. Sedangkan lingkup perkembangan yang terakhir mencakup seni yang meliputi anak mampu menikmati berbagai alunan lagu atau suara dan tertarik dengan kegiatan seni.

5. Evaluasi Pembelajaran di RA menggunakan alat penilaian berbentuk tes. Karena berbagai pertimbangan antara lain tujuan kegiatan peserta didik RA, maka metode tes jarang 
sekali digunakan. Tes buatan guru dapat dihasilkan oleh guru, termasuk guru RA. Selain tes, metode penilaian yang lain adalah non tes. Alat penilaian non tes banyak jenisnya yang sering digunakan di RA antara lain terdiri dari pemberian tugas, percakapan, observasi, portofolio, catatan anekdot, Skala penilaian, Unjuk kerja, Hasil Karya, Penggunaan instrumen standar, dan penilaian diri sendiri, Guru diperbolehkan untuk mengembangkan perangkat evaluasi atau assesment sendiri sesuai dengan kebutuhan. 
Fu'ad Arif Noor : Manajemen Peserta Didik Raudlatul Athfal (RA)

\section{DAFTAR PUSTAKA}

Abdul Munir, Seni Mengelola Lembaga Pendidikan Islam, Ciputat: Arta Karya Indonesia, 2010.

Abudin Nata, Perspektif Islam Tentang Pola Hubungan Guru dan Murid, Jakarta: Raja Grafindo Persada, 2001.

Akhmad Sudrajat, Konsep Dasar Peserta Didik, https://akhmadsudrajat.wordpress.com/2010/02/14/kon sep-dasar-manajemen-peserta-didik/ diakses pada 14 Agustus 2015.

Ali Imron, Manajemen Peserta Didik Berbasis Sekolah, Jakarta: Bumi Aksara, 2012.

Daryanto, Evaluasi Pendidikan, Jakarta: Rineka Cipta, 2007.

Departemen Agama Republik Indonesia, Pedoman Pelaksanaan Kurikulum Raudlatul Athfal, Jakarta: Direktorat Jenderal Kelembagaan Agama Islam, 2005.

Depdiknas., Pedoman Penilaian di Taman Kanak Kanak. Jakarta: Direktorat Pembinaan Taman Kanak-Kanak dan SD, 2006.

Hadari Nawawi, Organisasi Sekolah dan Pengelolaan Kelas Sebagai Lembaga Pendidikan. Jakarta: Gunung Agung, 1985.

http:/ /id.wikipedia.org/wiki/Peserta\%20didik?oldid=8321667 diakses pada 14 Agustus 2015.

Kamal Muhammad 'Isa, Manajemen Pendidikan Islam, Jakarta: Bumi Aksara, Cet. II, 2001.

Keputusan Direktur Jendral Pendidikan Islam Nomor 1714 tahun 2015, tentang Pedoman Penerimaan Peserta Didik Baru Tahun 2015-2016, Jakarta: 2015.

Lilis Maryati, Manajemen Peserta Didik, http://lilisaryanti.blogspot.com/2015/01/vbehaviorurldefaultvmlo.html diakses pada 14 Agustus 2015. 
Meilina Bustari, Manajemen Peserta Didik, Yogyakarta: FIP UNY, 2005.

Nenny Mahyuddin, Asesment Anak Usia Dini, Padang: UNP Press, 2008.

Peraturan Menteri Pendidikan dan Kebudayaan RI, Nomor: 137 Tahun 2014, Lampiran I Tentang Standar Nasional Pendidikan Anak Usia Dini, Jakarta: 2014.

Saefullah, Manajemen Pendidikan Islam, Bandung: Pustaka Setia, 2012 ,

Sitti Nadirah, Anak Didik Perspektif Nativisme, Empirisme, dan Konvergensi, Palu : Lentera Pendidikan, Vol. 16 No. 2 Desember 2013.

Trianto, Desain Pengembangan Pembelajaran Tematik Bagi Anak Usia Dini TK/RA \& Anak Usia Kelas Awal SD/MI, Jakarta : Kencana Prenada Media Group, 2011.

Undang-undang Republik Indonesia No. 20 tahun 2003 tentang Sistem Pendidikan Nasional (Sisdiknas).

Wiji Suwarno, Dasar-dasar Ilmu Pendidikan, Yogyakarta : Ar-Ruzz Media, 2006.

Yana Novita, Evaluasi pmbelajaran di TK, http://yananovita13.blogspot.com/2014/12/evaluasipembelajaran-di-tk.html di akses pada tanggal 14 Agustus 2015.

Zakiah Daradjat, Metodik Khusus Pengajaran Agama Islam, Jakarta: Bumi Aksara, 2001. 